Syntax Literate: Jurnal Ilmiah Indonesia p-ISSN: 2541-0849

e-ISSN: 2548-1398

Vol. 6, No. 5, Mei 2021

\title{
STUDI KOMPARASI MARITAL CONFLICT RESPONSE PADA PASANGAN SUAMI-ISTRI DI KOTA MAKASSAR (DITINJAU DARI MODEL EXIT, VOICE, LOYALTY, DAN NEGLECT)
}

\author{
Aldinel Fikri dan Anissa Lestari Kadiyono \\ Universitas Padjajaran (Unpad) Bandung Jawa Barat, Indonesia \\ Email: aldinel19001@mail.unpad.ac.id dan anissa.lestari@unpad.ac.id
}

\begin{abstract}
The response of the husband and wife in responding to conflict plays an important role in the stability and sustainability of the marriage. Constructive responses promote an increase in the couple's subjective evaluation of the quality of life in the context of a marital relationship. Meanwhile, destructive responses promote a downward trend in evaluating the personal quality of life. This study uses a quantitative approach with a comparative research design, to know the differences in responses between husbands and wives when responding to marriage conflicts in terms of 4 types of responses, namely exit, voice, loyalty, and neglect. The sample used in the quantitative procedure was a married couple who lived in Makassar City with an age range of 20 - 59 years $(n=350)$. The instrument used in the quantitative procedure was the EVLN instrument. The data analysis technique used is independent sample t-test. The result showes that, in general, male groups tended to respond to conflict with the voice response type while female groups tended to respond to conflict with the loyalty response type. Although there were no significant differences between the type of exit and neglect responses in the two measurement groups, in general it can be seen that the male group had a higher result than the female group on the destructive-active (exit) response type. On the other hand, in the type of passive-destructive response (loyalty), the average measurement value obtained by the group of women is higher than that of the male group. This indicates that there are different forms of self-involvement between men and women when responding to conflict
\end{abstract}

Keywords: marital coflict responses; quality of life; exit; voice; loyalty; neglect
Abstrak
Respon pasangan suami-istri dalam menanggapi konflik memegang peranan penting bagi stabilitas dan keberlangsungan pernikahan. Respon konstruktif dapat mempromosikan peningkatan evaluasi subjektif pasangan terkait kualitas hidup dalam konteks hubungan pernikahan. Sementara itu, respon destruktif mempromosikan kecenderungan penurunan evaluasi kualitas hidup secara personal. Penelitian ini menggunakan pendekatan kuantitatif dengan desain penelitian komparasi, dengan tujuan untuk mengetahui perbedaan respon antara suami dan istri ketika menanggapi konflik pernikahan yang ditinjau dari 4 tipe respon yakni konstruktif-aktif (voice), konstruktif-pasif (loyalty), destruktif-aktif (exit),
How to cite:
E-ISSN:
Published by:
Fikri, Aldinel., dan Anissa Lestari Kadiyono (2021) Studi Komparasi Marital Conflict Response Pada Pasangan Suami-Istri Di Kota Makassar (Ditinjau Dari Model Exit, Voice, Loyalty, Dan Neglect) Syntax Literate. 6(5)._http://dx.doi.org/10.36418/syntax-literate.v6i5.2685 2548-1398
Ridwan Institute 
destruktif-pasif (neglect). Sampel yang digunakan pada prosedur kuantitatif adalah pasangan suami-istri yang berdomisili di Kota Makassar dengan rentang usia 20 59 tahun $(\mathrm{n}=350)$. Instrumen yang digunakan pada prosedur kuantitatif adalah instrumen EVLN diadaptasi dan dimodifikasi untuk keperluan penelitian khususnya kesesuaian budaya. Teknik analisis data yang digunakan adalaah uji komparasi/uji beda independent sample t-test. Hasil penelitian menunjukkan bahwa, kelompok laki-laki secara umum cenderung merespon konflik dengan tipe respon voice sementara kelompok perempuan cenderung merespon konflik dengan tipe respon loyalty. Meskipun tidak ditemukan adanya perbedaan yang signifikan antara tipe respon exit dan neglect pada kedua kelompok pengukuran, namun secara umum dapat dilihat bahwa kelompok laki-laki memiliki nilai pengukuran yang lebih tinggi dari pada kelompok perempuan pada pengukuran tipe respon destruktif-aktif (exit). Sebaliknya, pada tipe respon destruktif-pasif (loyalty), rerata nilai pengukuran yang diperoleh oleh kelompok perempuan lebih tinggi dibandingkan kelompok laki-laki. Sehingga dapat disimpulkan bahwa, terdapat perbedaan bentuk pelibatan diri antara laki-laki dan perempuan ketika merespon konflik.

Kata Kunci: marital coflict responses; quality of life; exit; voice; loyalty; neglect

\section{Pendahuluan}

Manusia sebagai makhluk sosial memiliki dorongan yang kuat dalam memenuhi kebutuhan untuk diterima oleh orang lain (need to belong), kebutuhan untuk merasa terikat secara emosional dengan orang lain dalam sebuah hubungan yang intim (Myers, 2012). Bentuk pemenuhan need to belong pada orang dewasa, dapat termanifestasikan melalui bermacam cara diantaranya adalah, hubungan teman dekat, cohabitual (tinggal bersama namun tidak terikat secara resmi), berpacaran, pernikahan, dll. Di antara berbagai bentuk hubungan interpersonal yang intim (intimate interpersonal relationship), hubungan pernikahan lah yang secara umum dianggap sebagai suatu hubungan legal yang resmi diterima dalam tatanan sosial (Prihatinah, 2013).

Memelihara hubungan pernikahan menjadi hal yang sangat penting bagi pasangan suami-istri dalam menjaga keberlangsungan kehidupan pernikahannya (Regan, 2011). Setiap individu yang menikah cenderung mengharapkan pernikahan yang bahagia, berkualitas, dan bertahan lama dengan pasangan mereka (Hajizah, 2012). Harapan pasangan suami dan istri terhadap hubungan pernikahannya dapat saja memiliki kesamaan secara umum dalam hal mempertahankan dan merawat hubungan pernikahannya, namun dalam pemenuhan harapan tersebut tentunya melibatkan kompleksitas perilaku yang unik dan berbeda diantara keduanya (Sadarjoen \& Herlina, 2005).

Hasil penelitian yang dilakukan (Bradford et al., 2014) menyatakan bahwa, kegagalan dalam melakukan perilaku yang konstruktif bagi hubungan dan berterima oleh pasangan, merupakan awal dari ketidakstabilan pernikahan (unstable marriage). Kondisi yang tidak stabil dalam pernikahan dapat berdampak pada perceraian, keadaan disharmoni, dan kekerasan dalam rumah tangga (Zaldi., Suni. B., 2013). Pernyataan tersebut didukung oleh data CATAHU Komnas Perempuan Tahun 2017, yang 
menunjukkan bahwa, di Indonesia tercatat angka kekerasan dalam rumah tangga yakni 245.548 kasus kekerasan terhadap istri. Pada tahun 2005 tercatat angka perceraian 55.509 kasus, 2011 tercatat 320.000 kasus, dan pada tahun 2014 mencapai angka 382.211. Khususnya di Kota Makassar, angka perceraian yang terlaporkan di Pengadilan Agama, pada bulan Januari hingga bulan Juni 2016 sejumlah 885 kasus, dimana jumlah cerai talak (pengaduan perkara perceraian oleh suami) adalah sebanyak 203 kasus dan jumlah cerai gugat (pengaduan perkara perceraian oleh istri) adalah sebanyak 683 kasus.

Taylor, S. E., Peplau, L. A, (2015) menyatakan bahwa semua hubungan akan mengalami masalah dan kadang mengecewakan. Keberlangsungan hubungan bergantung pada bagaimana pasangan merespon masalah yang terjadi dan bagaimana pasangan melakukan coping atas kekecewaan yang dirasakannya dalam hubungan pernikahan. Dampak dari kondisi disharmoni cenderung mengarah pada peningkatan intensitas konflik dan berujung pada berakhirnya hubungan pernikahan itu sendiri (Sadarjoen \& Herlina, 2005). Dalam sebuah penelitian, ditemukan bahwa perilaku bermusuhan dan menghindari pasangan ketika terjadi konflik dalam pernikahan merupakan bentuk respon yang berkorelasi negatif dengan tingkat kepuasan dan stabilitas hubungan (Holman \& Jarvis, 2003). (Barnes, Brown, Krusemark, Campbell, \& Rogge, 2007) menambahkan bahwa respon individu yang secara aktif bermaksud mengakhiri hubungan melalui penghindaran, perilaku bermusuhan, tindakan kekerasan baik secara fisik atau verbal, melecehkan pasangan, sikap apatis atau tidak peduli terhadap kondisi pernikahan yang semakin memburuk seiring dengan semakin kompleksnya konflik yang terjadi, dan menjauhi pasangan, dapat dikategorikan dalam respon destruktif.

Sebaliknya, respon penyelesaian konflik yang dilakukan secara efektif terbukti dapat mengembangkan suatu hubungan kearah yang lebih menyenangkan bagi pasangan suami istri. Pertikaian dapat menjadi sarana mengungkap perasaan terdalam, dan memperbaharui hubungan untuk menciptakan hubungan yang lebih baik (Sadarjoen \& Herlina, 2005). Riset membuktikan bahwa perilaku aktif dalam mendiskusikan persoalan dan berkompromi dengan pasangan, berusaha memperbaiki hubungan, secara pasif menunggu hingga situasi hubungan membaik, merasa optimis bahwa masalah dalam hubungannya akan berakhir seiring berjalannya waktu dapat dikategorikan sebagai respon yang konstruktif dalam menanggapi konflik pernikahan (Bradbury \& Weiss, 2006); (Drigotas, Whitney, \& Rusbult, 1995). (Taylor, S. E., Peplau, L. A, 2015) menambahkan bahwa respon suami atau laki-laki cenderung bersifat aktif dalam menanggapi konflik pernikahan, terlepas dari dampak destruktif ataupun konstruktifnya perilaku yang ditampilkan dalam menanggapi konflik, sementara istri atau perempuan lebih diasosiasikan dengan respon yang bersifat pasif.

\section{A. Marital Conflict Response}

Dalam hubungan pernikahan, perselisihan atau perbedaan antar pasangan disebut sebagai marital conflict (konflik pernikahan), Fincham (2003) mendefinisikan konflik pernikahan sebagai keadaan suami-istri yang sedang 
menghadapi masalah dalam pernikahannya, hal tersebut dapat dilihat dari respon dan pola perilaku yang cenderung kurang harmonis ketika sedang menghadapi konflik. Konflik dalam pernikahan terjadi karena masing-masing individu membawa kebutuhan, keinginan, dan latar belakang yang unik dan berbeda.

Sejalan dengan penjelasan sebelumnya, (Sadarjoen \& Herlina, 2005) konflik pernikahan adalah konflik yang melibatkan pasangan suami istri dimana konflik memberikan efek atau pengaruh yang signifikan terhadap relasi kedua pasangan. Lebih lanjut (Sadarjoen \& Herlina, 2005) menyatakan bahwa konflik tersebut muncul karena adanya persepsi-persepsi dan harapan-harapan yang berbeda serta ditunjang oleh keberadaan latar belakang, kebutuhan-kebutuhan dan nilai-nilai yang mereka anut sebelum memutuskan untuk menjalin ikatan pernikahan.

\section{B. EVLN Model}

(Drigotas et al., 1995) mengidentifikasi respon individu dalam menanggapi konflik atau persoalan yang terjadi dalam suatu hubungan interpersonal khususnya hubungan yang memiliki komitmen seperti hubungan romantis atau hubungan pernikahan. Respon individu dibagi menjadi 2 jenis yaitu respon konstruktif (constructive response) dan respon negatif (negative response).

Respon individu tersebut disusun berdasarkan tipe EVLN response (Exit, Voice, Loyalty dan Neglect). Tipe respon tersebut menjadi prediktor yang kuat untuk melihat apakah hubungan tersebut akan terpelihara dan menjadi stabil ataukah hubungan tersebut akan berakhir (Drigotas et al., 1995). Berikut deskripsi tipe respon yang dimaksud:

1. Exit merupakan karakteristik respon individu yang secara aktif mengakhiri hubungan. Bentuk dari respon ini umumnya berupa menjauhi pasangan, memberikan perlakuan spesifik yang melukai pasangan baik secara fisik maupun psikis, melecehkan pasangan secara sengaja.

2. Voice merupakan karakteristik respon individu yang secara aktif berupaya untuk mendiskusikan problem penyebab konflik dalam hubungannya. Secara fundamental respon voice adalah upaya yang dilakukan individu untuk memperbaiki hubungan. Bentuk dari respon ini umumnya, membicarakan permasalahan dengan pasangan, berupaya mencari resolusi, menyarankan perbaikan hubungan.

3. Loyalty merupakan karakteristik respon dimana individu hanya menunggu secara pasif tetapi merasa optimis bahwa kondisi hubungan akan membaik seiring berjalannya waktu. Bentuk dari respon ini umumnya berupa menunggu situasi membaik, berharap, dan berdoa.

4. Neglect merupakan karakteristik respon pasif individu yang merujuk pada pembiaran situasi konflik semakin memburuk. Bentuk dari respon ini umumnya berupa, mengurangi waktu bersama, mengabaikan pasangan, menolak membahas problem yang menyebabkan konflik pernikahan. 
Beberapa penelitian terdahulu yang juga mengkaji tentang respon pasangan yang terlibat dalam hubungan intimasi, seperti hubungan dekat, berpacaran, cohabitual (tinggal bersama namun belum menikah), dan hubungan pernikahan. Bradford (2014) dalam penelitiannya, menganalisis kualitas pernikahan yang ditinjau berdasarkan coping yang dilakukan oleh pasangan suami-istri. Namun subjek pada penelitian tersebut adalah pasangan yang telah bercerai, sehingga peneliti berpendapat bahwa evaluasi individu terhadap kualitas pernikahan dan coping dilakukan oleh pasangan untuk saling menyesuaikan diri akan berbeda ketika dirinya sedang menjalin hubungan pernikahan dan ketika mereka telah bercerai. Oleh sebab itu, penelitian ini akan mengambil samper berpasangan (suami dan istri).

(Zaldi., Suni. B., 2013) mengkaji mengenai konsekuensi yang berpotensi ditimbulkan akibat kondisi pernikahan yang tidak stabil, hasil dari penelitian tersebut mengungkapkan bahwa kondisi pernikahan yang tidak stabil (unstable marriage) memiliki konsekuensi yaitu perceraian, disharmoni hubungan, dan kekerasan dalam rumah tangga. Berdasarkan hasil tersebut, penelitian ini kemudian ditujukan untuk melengkapi analisis tersebut, namun lebih memfokuskan pada respon-respon yang dilakukan pasangan suami-istri ketika dihadapkan pada situasi konflik, sebab pada dasarnya ketidakstabilan pernikahan salah satunya dapat bersumber dari bagaimana suami dan istri merespon situasi konflik yang terjadi dalam hubungan mereka. Konflik dalam pernikahan tidak dapat terhindarkan, keberhasilan pasangan dalam menangani konflik tersebut terletak pada bagaimana respon mereka ketika terjadi konflik (Sadarjoen \& Herlina, 2005).

Beberapa penelitian sebelumnya berfokus pada kajian tentang stabilitas pernikahan (Bradford et al., 2014); (Zaldi., Suni. B., 2013); (Holman \& Jarvis, 2003), sementara (Wilson, Regal, Papp, \& Kimble, 2009) menganalisis dampak yang ditimbulkan dari stabilitas pernikahan terhadap kesehatan fisik dan mental individu yang terlibat di dalamnya dalam hal ini pasangan suami-istri. Berdasarkan hal tersebut, peneliti kemudian memilih untuk memberi perhatian pada dampak yang ditimbulkan oleh respon pasangan suami-istri dalam menanggapi konflik terhadap evaluasi subjektif mereka secara personal terkait kualitas hidup. Sebab, pasangan yang berhasil menangani konflik secara efektif melalui perilaku yang memiliki dampak konstruktif bagi hubungan, dipercaya dapat meningkatkan kualitas hubungan, mempererat ikatan relasi, serta mempromosikan keadaan sejahtera bagi kedua pasangan tersebut (Myers, 2012).

Peneliti menggunakan model EVLN dari Rusbult (1987) untuk melihat dan membandingkan kecenderungan respon pasangan ketika menanggapi konflik yang terjadi dalam suatu hubungan dekat, misalnya pernikahan. Model ini umumnya digunakan untuk mengkategorikan tipe respon yang dilakukan individu dalam menanggapi konflik pernikahan. Oleh sebab itu, penelitian ini kemudian akan akan menganalisis perbedaan kecendurngan respon antara suami dan istri dalam menanggapi konflik pernikahan (marital conflict responses).

Berdasarkan latar belakang kultural sampel penelitian, seluruh penelitian terdahulu yang menjadi tinjauan pustaka dalam penelitian dilakukan pada kawasan 
dengan latar belakang kultural independen, dan hanya sedikit literatur serupa yang setting pelaksanaan penelitiannya dilakukan pada kawasan dengan latar belakang kultural interdependen, khususnya di Indonesia, dan secara lebih spesifik di Kota Makassar. Sehingga peneliti bermaksud untuk mengkaji isu penelitian dengan sampel yang memiliki latar belakang interdependen, namun dengan segala keterbatasan peneliti, penelitian ini hanya dilakukan pada sampel suami-istri yang berdomisili di Kota Makassar.

\section{Metode Penelitian}

\section{A. Jenis dan Desain Penelitian}

Penelitian ini menggunakan pendekatan kuantitatif dengan desain penelitian komparasi, Studi komparasi dalam penelitian ini menggunakan metode analisis independent sample t-test sebagai teknik analisis untuk menguji hipotesisi penelitian. Metode tersebut digunakan untuk melihat apakah terdapat perbedaan mean atau rerata dari dua kelompok sampel pengukuran (Riadi, 2016). Sehingga, dapat diketahui perbedaan kecenderungan dari dua kelompok sampel terhadap suatu variabel tertentu. Dalam hal ini, kelompok penelitian dibedakan menjadi kelompok istri (kelompok 1) dan kelompok suami (kelompok 2). Adapun variabel yang hendak diketahui perbedaan kecenderungannya adalah variabel marital conflict response yang terdiri dari respon exit, voice, loyalty, dan neglect.

Berdasarkan hal tersebut, hipotesis penelitian kemudan dibedakan menjadi 4 yaitu:

Hipotesis 1

$\mathrm{H}_{0}=$ Tidak terdapat perbedaan kecenderungan respon exit antara suami dan istri dalam menanggapi konflik pernikahan

$\mathrm{H}_{1} \quad=$ Terdapat perbedaan kecenderungan respon exit antara suami dan istri dalam menanggapi konflik pernikahan

Hipotesis 2

$\mathrm{H}_{0} \quad=$ Tidak terdapat perbedaan kecenderungan respon voice antara suami dan istri dalam menanggapi konflik pernikahan

$\mathrm{H}_{1} \quad=$ Terdapat perbedaan kecenderungan respon voice antara suami dan istri dalam menanggapi konflik pernikahan

Hipotesis 3

$\mathrm{H}_{0} \quad=$ Tidak terdapat perbedaan kecenderungan respon loyalty antara suami dan istri dalam menanggapi konflik pernikahan

$\mathrm{H}_{1}=$ Terdapat perbedaan kecenderungan respon loyalty antara suami dan istri dalam menanggapi konflik pernikahan

Hipotesis 4

$\mathrm{H}_{0}=$ Tidak terdapat perbedaan kecenderungan respon neglect antara suami dan istri dalam menanggapi konflik pernikahan

$\mathrm{H}_{1}=$ Terdapat perbedaan kecenderungan respon neglect antara suami dan 
istri dalam menanggapi konflik pernikahan

\section{B. Populasi dan Sampel}

Populasi dalam peneltian ini mengacu pada jumlah penduduk Kota Makassar menurut kelompok umur (20-59 tahun) yang berstatus menikah. Teknik pengambilan sampel dalam penelitian ini menggunakan teknik proportionate random sampling. Jumlah populasi yang didapatkan adalah sebesar 498.094 orang, yang tersebar di 14 kecamatan Kota Makassar.

Berdasarkan jumlah populasi tersebut, penentuan jumlah sampel dalam penelitian ini menggunakan tabel Isaac dan Michael pada taraf kesalahan 5\%, sehingga didapatkan jumlah sampel yaitu sebesar 348 orang yang dibulatkan menjadi 350 oang (175 perempuan dan 175 laki-laki).

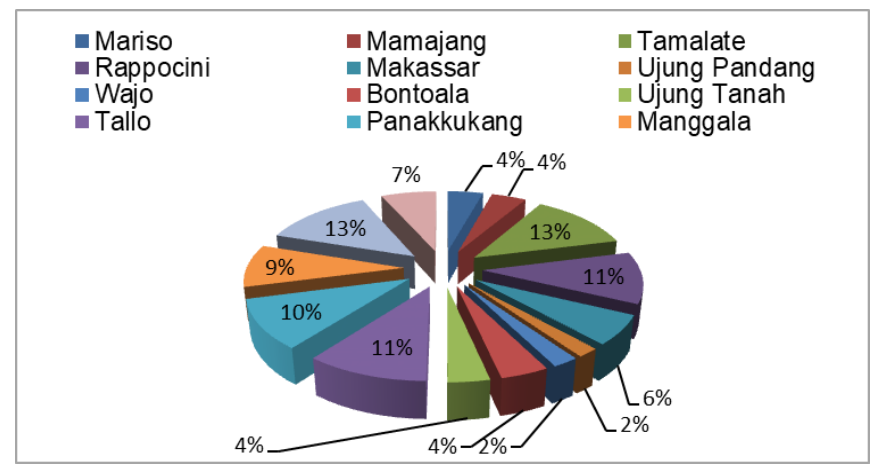

\section{Gambar 1}

\section{Presentase Sebaran Responden Menurut Kecamatan}

\section{Instrumen Pengukuran}

Variabel respon dalam menanggapi konflik pernikahan (marital conflict responses) merupakan suatu perbedaan reaksi individual dalam melakukan resolusi atau pemecahan masalah atas konflik yang terjadi dalam hubungan pernikahan, dimana reaksi ini dapat bersifat aktif maupun pasif dan memiliki dampak yang konstruktif ataupun destruktif bagi hubungan pernikahan. Variabel respon dalam menanggapi konflik pernikahan (marital conflict responses) dapat dilihat dengan menggunakan skala yang diadaptasi oleh penulis berdasarkan skala EVLN (Rusbult, 1987); (Drigotas et al., 1995). Jenis data yang diperoleh melalui skala EVLN adalah data interval.

Dalam proses pengisian skala, subjek diminta untuk memilih karakteristik respon yang paling menggambarkan diri subjek dalam menanggapi konflik pernikahan. Skala ini disusun berdasakan karakteristik respon dalam menanggapi konflik pernikahan yaitu exit, voice, loyalty, dan neglect. Nilai Cronbach's alpha pada setiap dimensi yaitu (exit $\boldsymbol{\alpha}=0.93$ ), (voice $\boldsymbol{\alpha}=0.93$ ), (loyalty $\boldsymbol{\alpha}=0.87$ ), (neglect $\boldsymbol{\alpha}=0.83$ ). Seluruh skor asli pada pengukuran masing-masing tipe respon dikonversi menjadi nilai logit person sesuai dengan kaidah Rasch Model. 


\section{Analisis}

Seluruh hipotesis penelitian dianalisis dengan menggunakan metode independent sample t-test. Namun, sebelum melakukan pengujian hipotesis, diperlukan uji asumsi terlebih dahulu sebagai prasyarat pengujian hipotesis. Data tiap variabel harus memenuhi uji asumsi yang mendasari metode analisis statistiknya. Sehingga demikian, sebelum melakukan uji independent sample t-test, terlebih dahulu dilakukan uji asumsi normalitas dan homogenitas terhadap sekumpulan data hasil pengukuran masing-masing variabel yang diteliti.

Analisis statistik deskriptif pada penelitian ini digunakan untuk menggambarkan distribusi data melalui pengukuran tendensi pusat, mencakup penentuan nilai rata-rata (mean), nilai tengah (median), nilai dengan frekuensi tertinggi pada sekumpulan data (modus), nilai minimum (minimum score), nilai maksimum (maximum score), dan simpangan baku (standard deviation). Set data yang digunakan dalam analisis statistik deskriptif pada penelitian ini adalah nilai logit person yang didapatkan melalui konversi skor mentah menjadi fungsi logarithm odd unit (logit) sesuai dengan kaidah pemodelan Rasch.

Prinsip dasar pemodelan Rasch mengacu pada model probabilistik, dimana diartikan bahwa setiap individu memiliki tingkat abilitas berbeda beda dan juga tingkat butir aitem alat ukur yang menghasilkan respon pada individu (Sumintono \& Widhiarso, 2014). Selain itu, berbeda dengan model klasik yang lebih mengutamakan total skor dari suatu instrumen penelitian, Rasch model menggunakan prinsip probabilitas pada setiap pilihan yang tersedia, sehingga akan dapat melihat hasil suatu pengukuran secara sistematis, lengkap dan dapat menjelaskan lebih banyak (Sumintono \& Widhiarso, 2014).

Dengan melakukan transformasi data menjadi nilai logit, secara langsung jenis data ordinal diubah menjadi data rasio, sehingga memungkinkan data tersebut dioperasikan dalam operasi aritmatika (Sumintono \& Widhiarso, 2014). Dengan dasar tersebut, data yang digunakan dalam penelitian ini adalah data logit. Penggunaan data logit berlaku baik pada uji asumsi, uji hipotesis, dan analisis deskriptif untuk mengetahui mengetahui ukuran statistik atas data dari masingmasing variabel yang diukur.

Pengukuran tipe respon exit untuk responden dengan jenis kelamin laki-laki memiliki ukuran statistik sebagai berikut, $M=0.0211, M d n=-0.0400, S D=$ 2.34905, max. score $=5.71$ dan min. score $=-5.38$. Sedangkan untuk responden dengan jenis kelamin perempuan memiliki $M=-0.5696, M d n=-0.5200, S D=$ 1.30648 , max.score $=3.22$ dan min. score $=-3.64$. Pengukuran tipe voice untuk responden dengan jenis kelamin laki-laki memiliki ukuran statistik sebagai berikut $M=-0.0063, M d n=0.1600, S D=1.64659$, max. score $=3.94$ dan min. sore $=-4.87$. Sedangkan untuk responden dengan jenis kelamin perempuan, $M=0.6413, M d n=$ $0.6200, S D=1.28008$, max . score $=3.21$ dan min. score $=-2.59$.

Pengukuran tipe loyalty untuk responden dengan jenis kelamin laki-laki, diketahui memiliki ukuran statistik sebagai berikut, $M=0.0663, M d n=-0.2300, S D$ 
$=1.97116$, msx . score $=4.22$ dan min. score $=-5.57$. Sedangkan untuk responden dengan jenis kelamin perempuan, $M=0.7570, M d n=0.7200, S D=1.41323$, max . score $=3.23$ dan min. score $=-2.73$. Pengukuran tipe neglect untuk responden dengan jenis kelamin laki-laki memiliki $M=-1.2562, M d n=-1.4000, S D=2.02792$, max. score $=4.13$ dan min. score $=-6.69$. Sedangkan untuk responden dengan jenis kelamin perempuan memiliki $M=-0.4597, M d n=-0.4200, S D=1.26244$, max . score $=3.52$ dan min. score $=-3.44$.

Sebaran data pada setiap variabel pengukuran yang dilakukan terhadap 2 kelompok pengukuran berdistribusi secara normal (lihat. Tabel 3). Hasil uji normalitas Kolmogorov-Smirnov pada kelompok pertama (istri) dan kelompok kedua (suami) diindikasikan berdistribusi secara normal. Distribusi data pada kelompok pertama untuk pengukuran tipe respon exit diketahui $\mathrm{D}(175)=0.994$, $\mathrm{p}=0.349$, tipe respon voice $\mathrm{D}(175)=0.950, \mathrm{p}=0.328$. tipe respon loyalty $\mathrm{D}(175)=1.303, \mathrm{p}=0.067$, dan tipe respon neglect $\mathrm{D}(175)=1.279, \mathrm{p}=0.076$. Sementara distribusi data pada kelompok kedua untuk pengukuran tipe respon exit diketahui $\mathrm{D}(175)=0.882, \mathrm{p}=0.418$, tipe respon voice $\mathrm{D}(175)=0.797, \mathrm{p}=0.549$. tipe respon loyalty $\mathrm{D}(175)=0.855, \mathrm{p}=0.457$, dan tipe respon neglect $\mathrm{D}(175)=1.141$, $\mathrm{p}=0.148$.

Hasil uji homogenitas yang dilakukan dengan mengkombinasikan skor antara kelompok 1 (istri) dan kelompok 2 (suami) pada setiap pengukuran variabel yang diteliti yakni tipe respon exit, voice, loyalty, dan neglect, ditemukan bahwa nilai signifikansi homogenitas tipe respon exit adalah 0.562 ( $>0.05), \quad F=0.337$. Signifikansi homogenitas tipe respon voice adalah 0.139 ( $\mathrm{p}>0.05), \quad \mathrm{F}=0.139$. Signifikansi homogenitas tipe respon loyalty adalah 0.248 ( $>>0.05), F=1.341$. Signifikansi homogenitas tipe respon neglect adalah 0.851 ( $\mathrm{p}>0.05), \mathrm{F}=0.035$. Berdasarkan hasil tersebut dapat dikatakan bahwa, seluruh data hasil pengukuran tipe respon exit, voice, loyalty, neglect pada kelompok 1 (istri) dan kelompok 2 (suami) bersifat homogen.

Tabel 1

Hasil uji homogenitas Levene's Test

\begin{tabular}{llrr}
\hline & & \multicolumn{2}{c}{$\begin{array}{c}\text { Levene's Test for Equality of } \\
\text { Variances }\end{array}$} \\
\cline { 3 - 4 } & & \multicolumn{3}{c}{ Sig. } \\
\hline Exit & Equal variances assumed & .337 & .562 \\
\hline Voice & Equal variances assumed & .139 & .710 \\
\hline Loyalty & Equal variances assumed & 1.341 & .248 \\
\hline Neglect & Equal variances assumed & .035 & .851 \\
\hline
\end{tabular}


Tabel 2

Hasil uji normalitas Kolmogorov-Smornov

\begin{tabular}{rlrrrr}
\hline \multicolumn{2}{c}{ Jenis Kelamin } & $\begin{array}{c}\text { EXIT } \\
\text { (logit) }\end{array}$ & $\begin{array}{c}\text { VOICE } \\
\text { (logit) }\end{array}$ & $\begin{array}{c}\text { LOYALITY } \\
\text { (logit) }\end{array}$ & $\begin{array}{c}\text { NEGLECT } \\
\text { (logit) }\end{array}$ \\
\hline & $\mathrm{N}$ & 175 & 175 & 175 & 175 \\
Perempuan (Istri) & $\mu$ & -.5696 & .64 & .76 & -.46 \\
& $\mathrm{STD}$ & 1.30648 & 1.280 & 1.413 & 1.262 \\
& $\mathrm{~K}-\mathrm{S}$ & .994 & .950 & 1.303 & 1.279 \\
& $p$ & .276 & .328 & .067 & .076 \\
\hline & $\mathrm{N}$ & 175 & 175 & 175 & 175 \\
Laki-laki (Suami) & $\mu$ & .0211 & -.01 & .07 & -1.26 \\
& $\mathrm{STD}$ & 2.34905 & 1.647 & 1.971 & 2.028 \\
& $\mathrm{~K}-\mathrm{S}$ & .882 & .797 & .855 & 1.141 \\
& $p$ & .418 & .549 & .457 & .148 \\
\hline
\end{tabular}

Tabel 3

Presentasi kategori responden pada pengukuran tipe respon Exit, Voice, Loyalty, Neglect

\begin{tabular}{|c|c|c|c|c|c|c|c|c|}
\hline \multirow[b]{2}{*}{ Kategori } & \multicolumn{2}{|c|}{ Exit } & \multicolumn{2}{|c|}{ Voice } & \multicolumn{2}{|c|}{ Loyalty } & \multicolumn{2}{|c|}{ Neglect } \\
\hline & $\begin{array}{c}\mathbf{L} \\
(\%)\end{array}$ & $\begin{array}{c}\mathbf{P} \\
(\%)\end{array}$ & $\begin{array}{l}\mathbf{L} \\
(\%)\end{array}$ & $\begin{array}{c}\mathbf{P} \\
(\%)\end{array}$ & $\begin{array}{l}\mathrm{L} \\
(\%)\end{array}$ & $\begin{array}{c}P \\
(\%)\end{array}$ & $\begin{array}{l}\mathbf{L} \\
(\%)\end{array}$ & $\begin{array}{c}\mathbf{P} \\
(\%)\end{array}$ \\
\hline Sangat & 19 & 4 & 6 & 0 & 8 & 0 & 11 & 3 \\
\hline Tinggi & $(11 \%)$ & $(2 \%)$ & $(3 \%)$ & $(0 \%)$ & $(5 \%)$ & $(0 \%)$ & $(6 \%)$ & $(2 \%)$ \\
\hline Tinggi & $\begin{array}{r}37 \\
(21 \%)\end{array}$ & $\begin{array}{r}53 \\
(30 \%)\end{array}$ & $\begin{array}{r}55 \\
(31 \%)\end{array}$ & $\begin{array}{r}56 \\
(32 \%)\end{array}$ & $\begin{array}{r}51 \\
(29 \%)\end{array}$ & $\begin{array}{r}61 \\
(35 \%)\end{array}$ & $\begin{array}{r}33 \\
(19 \%)\end{array}$ & $\begin{array}{r}54 \\
(31 \%)\end{array}$ \\
\hline Sedang & $\begin{array}{r}71 \\
(41 \%)\end{array}$ & $\begin{array}{r}65 \\
(37 \%)\end{array}$ & $\begin{array}{r}58 \\
(33 \%)\end{array}$ & $\begin{array}{r}55 \\
(31 \%)\end{array}$ & $\begin{array}{r}61 \\
(35 \%)\end{array}$ & $\begin{array}{r}63 \\
(36 \%)\end{array}$ & $\begin{array}{r}81 \\
(46 \%)\end{array}$ & $\begin{array}{r}68 \\
(39 \%)\end{array}$ \\
\hline Rendah & $\begin{array}{r}35 \\
(20 \%)\end{array}$ & $\begin{array}{r}39 \\
(22 \%)\end{array}$ & $\begin{array}{r}45 \\
(26 \%)\end{array}$ & $\begin{array}{r}50 \\
(29 \%)\end{array}$ & $\begin{array}{r}45 \\
(26 \%)\end{array}$ & $\begin{array}{r}36 \\
(21 \%)\end{array}$ & $\begin{array}{r}41 \\
(23 \%)\end{array}$ & $\begin{array}{r}35 \\
(20 \%)\end{array}$ \\
\hline $\begin{array}{l}\text { Sangat } \\
\text { Rendah }\end{array}$ & $\begin{array}{r}13 \\
(7 \%)\end{array}$ & $\begin{array}{r}14 \\
(8 \%)\end{array}$ & $\begin{array}{r}11 \\
(6 \%)\end{array}$ & $\begin{array}{r}14 \\
(8 \%)\end{array}$ & $\begin{array}{r}10 \\
(6 \%)\end{array}$ & $\begin{array}{r}15 \\
(9 \%)\end{array}$ & $\begin{array}{r}9 \\
(5 \%)\end{array}$ & $\begin{array}{r}15 \\
(9 \%)\end{array}$ \\
\hline Total & $\begin{array}{r}175 \\
(100 \%)\end{array}$ & $\begin{array}{r}175 \\
(100 \%)\end{array}$ & $\begin{array}{r}175 \\
(100 \%)\end{array}$ & $\begin{array}{r}175 \\
(100 \%)\end{array}$ & $\begin{array}{r}175 \\
(100 \%)\end{array}$ & $\begin{array}{r}175 \\
(100 \%)\end{array}$ & $\begin{array}{r}175 \\
(100 \%)\end{array}$ & $\begin{array}{r}175 \\
(100 \%)\end{array}$ \\
\hline
\end{tabular}

Berdasarkan tabel dan grafik tersebut, dapat diketahui bahwa kecenderungan distribusi data dari masing-masing pengukuran variabel berada pada kategori sedang. Variabel marital conflict responses pada tipe exit didapatkan persentase sebesar $11 \%$ pada kategori sangat tinggi, 37\% pada kategori tinggi, $41 \%$ pada kategori sedang, $20 \%$ pada kategori rendah dan $7 \%$ pada kategori sangat rendah untuk jenis kelamin laki-laki (suami). Sedangkan untuk jenis kelamin perempuan (istri), didapatkan persentase sebesar $2 \%$ pada kategori sangat tinggi, 30\% pada kategori tinggi, 37\% pada kategori sedang, 22\% pada kategori rendah, dan $14 \%$ pada kategori sangat rendah. Pengukuran tipe voice didapatkan persentase sebesar $3 \%$ pada kategori sangat tinggi, 31\% pada kategori tinggi, 33\% pada kategori sedang, $26 \%$ pada kategori rendah dan $6 \%$ pada kategori sangat rendah untuk jenis kelamin laki-laki (suami). Sedangkan untuk jenis kelamin perempuan (istri), didapatkan persentase sebesar $0 \%$ pada kategori sangat tinggi, 32\% pada kategori tinggi, 31\% pada kategori sedang, 29\% pada kategori rendah, dan $18 \%$ pada kategori sangat rendah. 
Tipe loyalty didapatkan persentase sebesar 5\% pada kategori sangat tinggi, $29 \%$ pada kategori tinggi, 35\% pada kategori sedang, 26\% pada kategori rendah dan $6 \%$ pada kategori sangat rendah untuk jenis kelamin laki-laki (suami). Sedangkan untuk jenis kelamin perempuan (istri), didapatkan persentase sebesar 0\% pada kategori sangat tinggi, 35\% pada kategori tinggi, 36\% pada kategori sedang, $21 \%$ pada kategori rendah, dan $9 \%$ pada kategori sangat rendah.

Dimensi neglect didapatkan persentase sebesar $6 \%$ pada kategori sangat tinggi, $19 \%$ pada kategori tinggi, $46 \%$ pada kategori sedang, $23 \%$ pada kategori rendah dan $5 \%$ pada kategori sangat rendah untuk jenis kelamin laki-laki (suami). Sedangkan untuk jenis kelamin perempuan (istri), didapatkan persentase sebesar 2\% pada kategori sangat tinggi, 31\% pada kategori tinggi, 39\% pada kategori sedang, 20\% pada kategori rendah, dan $9 \%$ pada kategori sangat rendah.

\section{Hasil dan Pembahasan}

Studi komparasi dilakukan untuk melihat apakah terdapat perbedaan mean atau rerata dari dua kelompok sampel. Dengan melakukan uji komparasi, dapat diketahui informasi mengenai kelompok sampel mana yang lebih cenderung melakukan tipe respon exit, voice, loyalty, neglect. Hasil uji komparasi antara kelompok sampel perempuan (istri) laki-laki (suami) pada 4 karakteristik respon, dapat dilihat pada tabel dibawah ini:

Tabel 4

Hasil uji independent sample t-test

\begin{tabular}{lrrrr}
\hline & \multicolumn{4}{c}{ T-Test For Equality Of Means } \\
\cline { 2 - 5 } & \multicolumn{1}{c}{$\mathbf{t}$} & df & $\boldsymbol{p}$ & $\begin{array}{c}\text { Mean } \\
\text { Difference }\end{array}$ \\
\hline Exit & -0.19 & 348 & 0.846 & -0.09143 \\
Voice & -3.26 & 348 & 0.001 & -1.63429 \\
Loyalty & 2.73 & 348 & 0.007 & 1.40571 \\
Neglect & 0.59 & 348 & 0.555 & 0.32 \\
\hline
\end{tabular}

Berdasarkan tabel tersebut dapat dilihat bahwa, hanya tipe respon voice dan loyalty yang memiliki perbedaan signifikan dengan nilai signifikansi dibawah 0.05 (voice $=0.001, \mathrm{p}<0.05$, loyalty $=0.007, \mathrm{p}<0.05$ ) mengacu pada nilai tersebut, dapat dinyatakan bahwa terdapat perbedaan yang signifikan antara kelompok responden lakilaki dan perempuan dalam pengukuran tipe respon voice dan loyalty.

Melalui tabel 4, dapat dilihat hasil uji independent sample t-test yang dilakukan terhadap dua kelompok pengukuran yaitu kategori istri sebagai kelompok 1 dan kategori suami sebagai kelompok 2. Hasil uji komparasi rerata skor pengukuran tiap tipe respon konflik yakni exit, voice, loyalty, dan neglect ditemukan bahwa, hanya tipe respon voice dan tipe respon loyalty yang memiliki perbedaan signifikan, sementara 2 tipe lainnya yaitu tipe exit dan neglect tidak memiliki perbedaan yang signifikan. Simpulan tersebut mengacu pada nilai yang ditampilkan pada tabel uji independent sample t-test, dimana 
hasil uji komparasi pada tipe respon exit diketahui, df (348), $\mathrm{t}=(-0.19), \mathrm{p}=0.846 / \mathrm{p}>0.05$ (two-tailed). Tipe respon neglect diperoleh nilai df (348), $\mathrm{t}=0.59, \mathrm{p}=0.555 / \mathrm{p}>0.05$ (two-tailed). Berdasarkan hasil tersebut, sehingga dinyatakan bahwa hipotesis null $\left(\mathrm{H}_{0}\right)$ pada hipotesis penelitian 1 dan 4 diterima, dan $\mathrm{H}_{1}$ ditolak. Dengan demikian dapat simpulkan bahwa tidak terdapat perbedaan signifikan, baik pada kecenderungan respon exit maupun kecenderungan tipe respon neglect antara suami dan istri dalam menanggapi konflik pernikahan.

Sebaliknya, hasil uji komparasi pada tipe respon voice diperoleh nilai $\mathrm{df}(348), \mathrm{t}=(-$ 3.262), $\mathrm{p}=0.001 / \mathrm{p}<0.05$ (two-tailed), sementara hasil yang diperoleh dari hasil uji komparasi pada tipe respon loyalty didapatkan nilai $\mathrm{df}(348), \mathrm{t}=(2.737), \mathrm{p}=0.001 / \mathrm{p}<0.05$ (two-tailed). Berdasarkan hasil tersebut, sehingga dinyatakan bahwa hipotesis null $\left(\mathrm{H}_{0}\right)$ pada hipotesis penelitian 2 dan 3 ditolak, dan $\mathrm{H}_{1}$ diterima. Dengan demikian dapat simpulkan bahwa terdapat perbedaan yang signifikan, baik pada kecenderungan tipe respon voice maupun kecenderungan tipe respon neglect antara suami dan istri dalam menanggapi konflik pernikahan. Telah diketahui bahwa, hanya tipe respon voice dan loyalty yang memiliki perbedaan signifikan antar 2 kelompok pengukuran (istri dan suami). Sehingga kemudian, analisis dapat dilanjutkan dengan mengukur effect size dari dua tipe respon tersebut.

Effect size yang diperoleh pada tipe respon voice adalah Cohen's $d=((-0.01)-$ $0.64) / 1.474=0.440$, sementara effect size pada tipe respon loyalty adalah $d=(0.07-$ $0.76) / 1.714=0.402$. Mengacu pada hasil tersebut, sehingga kategori effect size untuk kedua tipe respon tersebut dapat dikategorikan sebagai medium effect.

Tidak ditemukan adanya perbedaan yang signifikan antara kelompok laki-laki (suami) dan perempuan (istri) dalam tipe respon destruktif-aktif/exit dan tipe respon destruktif-pasif/neglect. Meskipun demikian, hasil uji komparasi tetap dapat digunakan untuk melihat kecenderungan respon atau tren yang berlaku pada dua kelompok analisis. Hasil uji komparasi untuk tipe respon exit dan neglect antara kelompok lakilaki menyatakan bahwa laki-laki cenderung melakukan tipe respon exit sementara perempuan cenderung melakukan tipe respon neglect.

Disisi lain, untuk tipe respon voice dan loyalty, ditemukan adanya perbedaan yang signifikan, dimana kelompok laki-laki (suami) cenderung memilih tipe respon konstruktif-aktif/voice dan perempuan (istri) cenderung memilih tipe respon konstruktifpasif/loyalty dalam menanggapi konflik pernikahan. Sehingga dapat disimpulkan bahwa terdapat perbedaan respon antara laki-laki dan perempuan ketika menanggapi konflik pernikahan, dalam penelitian ini responden laki-laki (suami) cenderung melakukan tipe respon yang bersifat aktif, dan responden perempuan (istri) cenderung melakukan tipe respon yang bersifat pasif, terlepas dari dampak konstruktif ataupun destruktif dari respon yang dilakukan.

Hasil penelitian tersebut memiliki kesesuaian dengan penelitian terdahulu yang dilakukan oleh (Kuncewicz, 2011), laki-laki cenderung melakukan resolusi aktif yaitu voice dan exit $(\mathrm{t}=-4.74)$, sementara perempuan lebih melakukan resolusi pasif yaitu neglect dan loyalty $(\mathrm{t}=5.27)$. Bentuk perilaku pasif yang umumnya dilakukan 
perempuan sebagai resolusi atas konflik pernikahan adalah dengan menerima keadaan seperti, memberi respek kepada suami karena suami dianggap sebagai kepala keluarga, memberi perhatian kepada suami, mencintai pasangan, berada pada kontinum konstruktif, sementara pengabaian dan penghindaran pasangan seperti menghindari percakapan, merasa puas dengan diri sendiri tanpa adanya pasangan berada pada kontinum destruktif (Asadi et al., 2016). Disisi lain, responden laki-laki lebih cenderung terlaporkan melakukan resolusi konflik secara aktif, seperti berupaya mendiskusikan masalah, menyarankan untuk pergi berkonsultasi, yang berada pada kontinum tindakan konstruktif, sementara perilaku mendominasi dan memperbaiki keadaan dengan menggunakan power, seperti melakukan tindakan agresif, melakukan reaksi disertai kekerasan baik secara fisik ataupun verbal, dan berselisih, yang berada pada kontinum perilaku destruktif (Asadi et al., 2016).

Penelitian ini hanya menggambarkan perbedaan masing-masing tipe respon (EVLN) pasangan suami-istri dalam menanggapi marital conflict. Faktor lain seperti, usia pernikahan, jumlah anak, jumlah pendapatan, tingkat pendidikan, tidak termasuk dalam analisis. Sehingga terdapat adanya kemungkinan demografi responden juga turut memberi pengaruh terhadap tinggi rendahnya kualitas hidup. Penelitian ini kurang menggali dinamika konflik dan efektivitas respon terhadap konflik yang dilakukan oleh individu, sehingga belum diketahui sejauh mana suatu respon tertentu berhasil mengatasi konflik yang terjadi dalam hubungan interpersonal dan seperti apakah dampaknya bagi individu-individu yang terlibat dalam hubungan tersebut. Penelitian ini tidak menyertakan skala kepatutan sosial ketika memberikan kuesioner yang memuat aitem-aitem sensitif. Sehingga berkemungkinan dijawab secara normatif, dan terdapat kemungkinan responden memberikan respon yang patut secara sosial (social desirable responding) dalam menjawab kuesioner. Oleh sebab itu, terdapat kemungkinan respon normatif yang diberikan subjek namun tidak dapat diukur.

\section{Kesimpulan}

Respon individu ketika menanggapi konflik dapat dilihat dari 2 kontinum, yaitu kontinum dampak dan kontinum pelibatan diri. Kontinum dampak merujuk pada konsekuensi yang ditimbulkan sebagai akibat dari respon yang ditampilkan, adapun konsekuensi atau dampak tersebut dapat bersifat konstruktif atau destruktif bagi hubungan. Sementara kontinum intensitas pelibatan diri, merujuk pada keterlibatan individu secara aktif ataupun pasif ketika dihadapkan pada situasi konflik. Perilaku spesifik yang umumnya dilakukan pasangan suami-istri ketika dihadapkan pada situasi konflik dapat digolongkan menjadi 4 tipe yaitu konstruktif-aktif (voice), konstruktifpasif (loyalty), destruktif-aktif (exit), dan destruktif-pasif (neglect). Tipe respon konstruktif-aktif terdiri dari perilaku membicarakan masalah, saling mendiskusikan keinginan, secara asertif menegur kesalahan, dan bersikap tegas. Tipe respon konstruktif-pasif meliputi perilaku mengakomodir kesalahan pasangan, memberikan toleransi atas kesalahan pasangan, berusaha menghadapi masalah dengan tenang, berusaha bersabar, mengalah, memaafkan pasangan, berdoa, dan mendengarkan aspirasi 
pasangan. Sementara tipe respon destruktif-aktif terdiri dari perilaku berkata kasar, cekcok, mendorong, mencakar, menyakiti diri sendiri, menjalin hubungan dengan orang lain, pisah ranjang, dan menggugat cerai. Sedangkan tipe respon destruktif-pasif meliputi perilaku membiarkan masalah berhenti tanpa menyelesaikan, membiarkan masalah berlarut, meninggalkan pasangan, mendiami pasangan, tidak peduli dengan pasangan, dan keluar rumah.

Pada penelitian ini, ditemukan adanya kecenderungan perbedaan respon antara kelompok laki-laki (suami) dan perempuan (istri) ketika menanggapi konflik dalam hubungan pernikahan, khususnya respon yang terkait dengan kontinum pelibatan diri, kelompok laki-laki, secara signifikan cenderung lebih aktif dalam merespon konflik sementara kelompok perempuan cenderung lebih pasif. Kelompok laki-laki secara umum cenderung merespon konflik dengan tipe respon voice sementara kelompok perempuan cenderung merespon konflik dengan tipe respon loyalty. Meskipun tidak ditemukan adanya perbedaan yang signifikan antara tipe respon exit dan neglect pada kedua kelompok pengukuran, namun secara umum dapat dilihat bahwa kelompok lakilaki memiliki nilai pengukuran yang lebih tinggi dari pada kelompok perempuan pada pengukuran tipe respon destruktif-aktif (exit). Sebaliknya, pada tipe respon destruktifpasif (loyalty), rerata nilai pengukuran yang diperoleh oleh kelompok perempuan lebih tinggi dibandingkan kelompok laki-laki. Hal ini mengindikasikan adanya perbedaan bentuk pelibatan diri antara laki-laki dan perempuan ketika merespon konflik. 


\section{BIBLIOGRAFI}

Asadi, Zahra Sadat, Sadeghi, Roya, Taghdisi, Mohammad Hossein, Zamani-Alavijeh, Freshteh, Shojaeizadeh, Davoud, \& Khoshdel, Ali Reza. (2016). Sources, Outcomes, and Resolution of Conflicts in Marriage among Iranian women: A qualitative study. Electronic Physician, 8(3), 2057. Google Scholar

Barnes, Sean, Brown, Kirk Warren, Krusemark, Elizabeth, Campbell, W. Keith, \& Rogge, Ronald D. (2007). The role of mindfulness in romantic relationship satisfaction and responses to relationship stress. Journal of Marital and Family Therapy, 33(4), 482-500. Google Scholar

Bradbury, Thomas N., \& Weiss, Robert L. (2006). The developmental course of marital dysfunction. Cambridge University Press. Google Scholar

Bradford, Angela B., Adler-Baeder, Francesca, Ketring, Scott A., Bub, Kristen L., Pittman, Joe F., \& Smith, Thomas A. (2014). Relationship quality and depressed affect among a diverse sample of relationally unstable relationship education participants. Family Relations, 63(2), 219-231. Google Scholar

Drigotas, Stephen M., Whitney, Gregory A., \& Rusbult, Caryl E. (1995). On the peculiarities of loyalty: A diary study of responses to dissatisfaction in everyday life. Personality and Social Psychology Bulletin, 21(6), 596-609. Google Scholar

Hajizah, Yulida Nur. (2012). Hubungan antara komunikasi intim dengan kepuasan pernikahan pada masa pernikahan 2 tahun pertama. Universitas Indonesia. Google Scholar

Holman, Thomas B., \& Jarvis, Mark O. (2003). Hostile, volatile, avoiding, and validating couple-conflict types: An investigation of Gottman's couple-conflict types. Personal Relationships, 10(2), 267-282. Google Scholar

Kuncewicz, D. (2011). Conflict Resolution And Relational Patterns In The Families Of Origin Of Women And Men. Psychology Of Language And Communication, 1(15), 89-106.

Myers, D. G. (2012). Psikologi Sosial. Jakarta: Salemba Humanika.

Prihatinah, Tri Lisiani. (2013). Tinjauan Filosofis Undang-Undang Nomor 1 Tahun 1974. Jurnal Dinamika Hukum, 8(2), 166-172. Google Scholar

Regan, P. (2011). Close Relationships. New York: Routledge T\&F.

Riadi, Edi. (2016). Statistika penelitian (analisis manual dan IBM SPSS). Yogyakarta: Andi. Google Scholar

Rusbult, Caryl E. (1987). Responses to dissatisfaction in close relationships: The exitvoice-loyalty-neglect model. Google Scholar 
Aldinel Fikri dan Anissa Lestari Kadiyono

Sadarjoen, Sawitri Supardi, \& Herlina, Rose. (2005). Konflik Marital: pemahaman konseptual, aktual dan alternatif solusinya. Refika Aditama. Google Scholar

Sumintono, Bambang, \& Widhiarso, Wahyu. (2014). Aplikasi model Rasch untuk penelitian ilmu-ilmu sosial (edisi revisi). Trim Komunikata Publishing House. Google Scholar

Taylor, S. E., Peplau, L. A, \&. Sears. D. O. (2015). Psikologi Sosial (Edisi 12). Jakarta : Kencana.

Wilson, Dalziel J., Regal, Cindy A., Papp, Scott B., \& Kimble, H. J. (2009). Cavity optomechanics with stoichiometric SiN films. Physical Review Letters, 103(20), 207204. Google Scholar

Zaldi., Suni. B., \&. Mukhlis. (2013). Dysfunction Of The Husband-Wife Young Couple And Its Impact. Jurnal Tesis Pmis-Untan-Pss-2013.

Copyright holder:

Aldinel Fikri dan Anissa Lestari Kadiyono (2021)

First publication right:

Journal Syntax Literate

This article is licensed under:

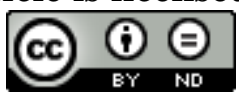

